\title{
The Phenomenon of High Hardness Values on the S-Phase Layer of Austenitic Stainless Steel via Screen Plasma Nitriding Process
}

\author{
Sang-Gweon Kim¹, Kook-Hyun Yeo', Yong-Ki Cho' ${ }^{1}$ Jae-Hoon Lee', Masahiro Okumiya² \\ ${ }^{1}$ Heat Treatment R\&D Group, Korea Institute of Industrial Technology (KITECH), Siheung, Republic of Korea \\ ${ }^{2}$ Toyota Technological Institute, Nagoya, Japan \\ Email: kimsg@kitech.re.kr
}

How to cite this paper: Kim, S.-G., Yeo, K.-H., Cho, Y.-K., Lee, J.-H. and Okumiya, M. (2018) The Phenomenon of High Hardness Values on the S-Phase Layer of Austenitic Stainless Steel via Screen Plasma Nitriding Process. Advances in Materials Physics and Chemistry, 8, 257-268. https://doi.org/10.4236/ampc.2018.86017

Received: May 2, 2018

Accepted: June 26, 2018

Published: June 29, 2018

Copyright $\odot 2018$ by authors and Scientific Research Publishing Inc. This work is licensed under the Creative Commons Attribution International License (CC BY 4.0).

http://creativecommons.org/licenses/by/4.0/

\begin{abstract}
The purpose of this study is to improve the surface properties of austenitic stainless steel using the double-folded electrode screen plasma nitriding (SPN) process. In general, the S-phase is well-known for its excellent properties such as improved hardness and wear resistance along with sustained corrosion resistance. The concentrated nitrogen via SPN process was injected to form S-phase with time at $713 \mathrm{~K}$. This study was carried out under the conditions of 44 at $\%$ of nitrogen injection, which was higher than 25 at\% known as the condition of no precipitation of S-phase formed by the SPN process, and $20 \mathrm{~K}$ higher than the maximum temperature without precipitation phase. The hardness analysis of stainless steel sample treated by the SPN process at 713 $\mathrm{K}$ showed a much higher value than the typical nitriding hardness at a depth of lower nitrogen than the maximum nitrogen concentration. The SPN 20 $\mathrm{hr}$ treated specimen showed the average value of $2339 \mathrm{HV}$ while $40 \mathrm{hr}$ showed the average value of $2215 \mathrm{HV}$. The result is attributed to the concentrated nitrogen formed in the SPN process reacting with the alloying elements contained in the base material to form fine precipitates, thus producing a synergy effect of the extreme hardening effect; that is, the movement of precipitates and dislocations due to the GP-zone (Guinier-Preston zone).
\end{abstract}

\section{Keywords}

Double-Folded Electrode, Austenitic Stainless Steel (ASS), Screen Plasma Nitriding (SPN) Process, S-Phase, Corrosion Resistance, High Hardness

\section{Introduction}

The double-folded electrode Screen Plasma Nitriding (SPN) process of austenitic 
stainless steel (ASS) at low temperatures has been extensively studied to understand the factors influencing the formation of nitrogen expanded austenite (S-phase) [1] [2] [3] [4] [5]. The S-phase provides high hardness and wear-resistance, and for this reason, there are potential demands for S-phase from the industries of machinery, mold tools and automotive parts [4].

The S-phase on the surface of ASS is thermodynamically unstable when it is oversaturated with interstitial atoms such as nitrogen and carbon. This is because the state of oversaturation induces internal stress that distorts lattice and increases the volume of ASS [6].

The residual stress, or internal stress, of ASS leads to the formation of CrN-precipitates after nitriding, which results in severe corrosion through the formation of galvanic cells [7]. Also, the formation of cracks can initiate from the locations with high composition-induced stress in ASS.

Christiansen suggested that high nitrogen potential is located near the surface of the S-phase, which leads to the push-out of grain for relaxing the stress. This implies that corrosion can initiate at the locations where grain push-out occurs [8]. Indeed, the phenomena of corrosion were observed in the S-phase when the sample was immersed in an acid mixture of $50 \% \mathrm{HCl} / \mathrm{H}_{2} \mathrm{SO}_{4}(3: 1)$ and $50 \% \mathrm{H}_{2} \mathrm{O}$, as shown in Figure 1.

Christiansen et al. also proposed a corrosion model based on the simulation for the relationship between the amount of nitrogen diffused into the matter and the distribution of residual stress during gas nitriding process [8]. He also mentioned that the formation of cracks is likely to occur above 25 at $\%$ of the amount

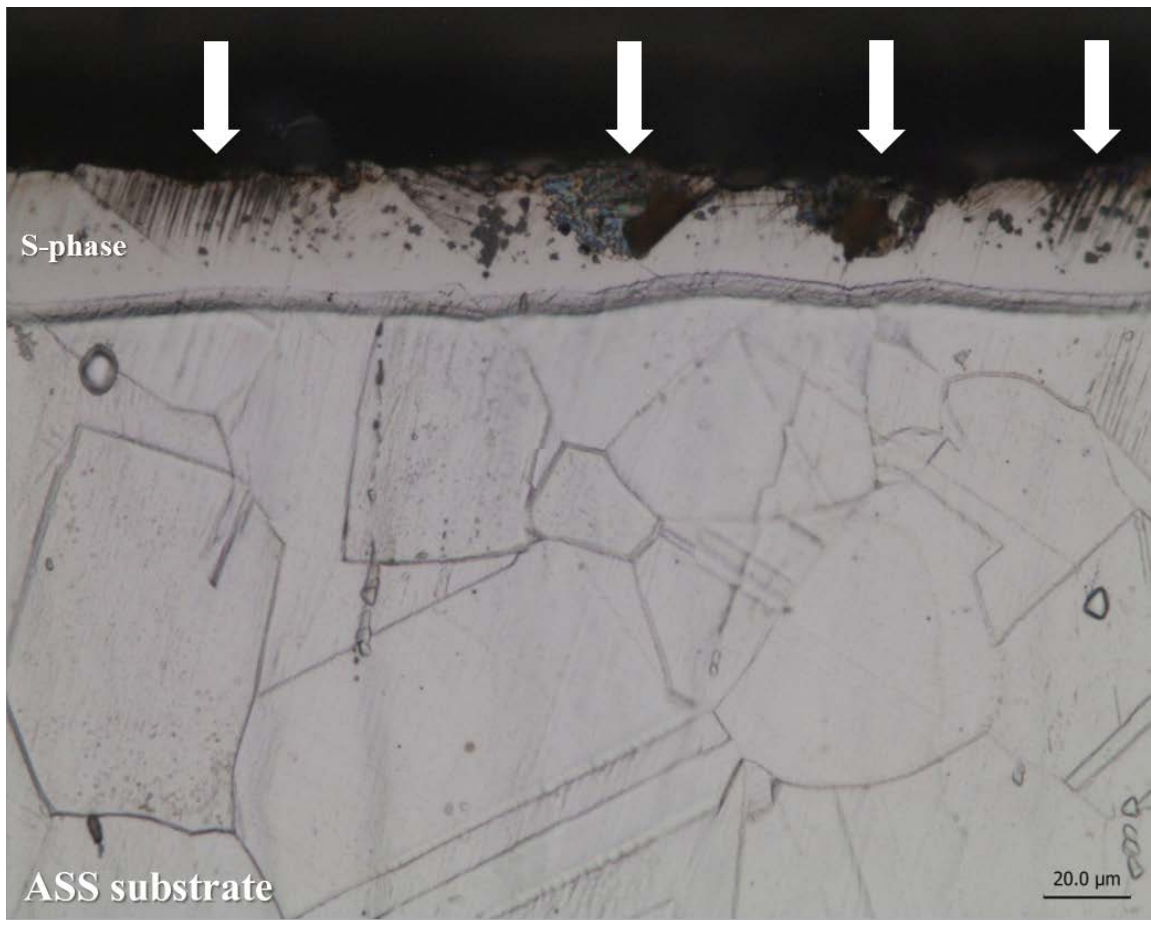

Figure 1. Corrosion of the S-phase after immersed in an acid mixture $\left(50 \% \mathrm{HCl} / \mathrm{H}_{2} \mathrm{SO}_{4}\right.$ (3:1) and $50 \% \mathrm{H}_{2} \mathrm{O}$ ). The location after corrosion test is indicated by a white arrow. 
of nitrogen atoms in the S-phase.

Kim et al. referred to the principle of high density nitrogen generation by screen plasma technology and reported a very high nitrogen concentration compared to other nitriding processes at a nitrogen concentration of 44 at $\%$ and a temperature of $713 \mathrm{~K}$ [9].

This study reports the result showing the particularly high hardness even when considering that the error range is high since the micro hardness is very large during the process of controlling the phase formation through aging by slow cooling after injecting concentrated nitrogen in the precipitation zone of S-phase for the study of the formation of more hardened surface despite the loss of nitride layer by precipitate.

\section{Experimental Procedures}

Disc samples of ASS with the size of $10 \mathrm{~mm}$ by $30 \mathrm{~mm}$ were prepared. The nominal composition of the ASS (AISI 316L or JIS-SUS316L) was $0.03 \% \mathrm{C}, 2 \% \mathrm{Mn}$, $0.75 \% \mathrm{Si}, 0.045 \% \mathrm{P}, 0.03 \% \mathrm{~S}, 16 \%-18 \% \mathrm{Cr}, 10 \%-14 \% \mathrm{Ni}$, and $0.1 \% \mathrm{~N}$ (Table 1).

The bright polished ASS was treated using a SPN equipment (Figure 2) as follows. The samples were placed in a double-folded screen electrode set-up on the electrically insulated plate (cathode) surrounded by the chamber wall (anode). The double-folded screen electrode was a mesh cylinder of $700 \mathrm{~mm}$ in

Table 1. Chemical composition of AISI 316L (ASS) used in the experiments (\%).

\begin{tabular}{ccccccccc}
\hline $\begin{array}{c}\text { Chemical } \\
\text { composition }\end{array}$ & $\mathrm{C}$ & $\mathrm{Cr}$ & $\mathrm{Mn}$ & $\mathrm{N}$ & $\mathrm{Ni}$ & $\mathrm{P}$ & $\mathrm{S}$ & $\mathrm{Si}$ \\
\hline $\begin{array}{c}\text { AISI316L } \\
\text { (ASS) }\end{array}$ & 0.03 & $16.0-18.0$ & 2.0 & 0.1 & $10.0-14.0$ & 0.045 & 0.03 & 0.75 \\
\hline
\end{tabular}

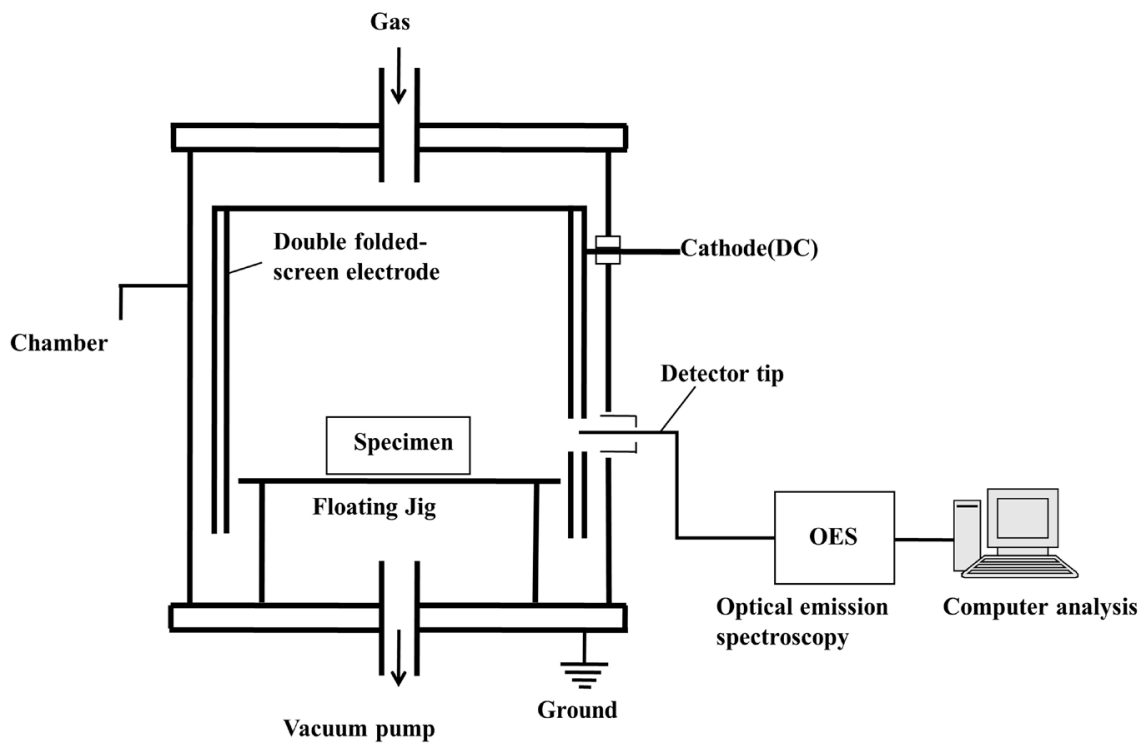

Figure 2. Illustration of the SPN set-up. 
diameter and was $900 \mathrm{~mm}$ high with a $1 \mathrm{~mm}$ perforated AISI 304 steel sheet. During the SPN processing, DC power (maximum output: $600 \mathrm{~V} / 50 \mathrm{~A}$ ) was applied to the double-folded screen electrode to increase the temperature. The processing temperatures for SPN process were $713 \mathrm{~K}$, respectively, at fixed 0.15 Torr for $4,10,20$, and 40 hours. During the process, $\mathrm{N}_{2} / \mathrm{H}_{2}$ gas with gas ratio of 1 to 3 were used with $320 \mathrm{sccm}$.

The microstructure of the samples after SPN treated sample was observed using SEM/EDS (FEI Hong Kong Company, NNS-450 and Bruker LN2 free SDD EDS). XRD data were collected using a PANalytical X-ray diffractometer with $\mathrm{Cu} \mathrm{Ka}$ radiation $(\lambda=1.5405 \AA)$ for the investigation of phase composition. Hardness and depth profile of the samples were measured using a micro-Vickers hardness tester (Matsuzawa, MMT-3).

\section{Results and Discussion}

The SPN process enables the diffusion of a high concentration of nitrogen atoms into ASS at relatively low temperatures compared to other nitriding processes such as gas nitriding. The effectiveness of double-folded screen electrode in plasma nitriding is attributed to the ease of diffusion with smaller size of active nitrogen species such as neutral nitrogen $(\mathrm{N}), \mathrm{NH}_{\mathrm{x}}, \mathrm{N}_{2}^{*}$ and $\mathrm{N}_{2}^{+}$generated by plasma nitriding. The concentration of nitrogen atoms is one of the main variables that determine the diffusion depth according to Fick's law. Also, the temperature as a processing parameter is the driving force for diffusion of nitrogen atoms into the ASS substrate. For example, diffusion depth of the nitrogen atoms is determined by the temperature during the nitriding process [9] [10].

Figure 3 shows the cross section images of samples treated with the SPN process at the temperature of $713 \mathrm{~K}$ for (a) $8 \mu \mathrm{m}$ thickness at 4 , (b) $14 \mu \mathrm{m}$ thickness at 10, (c) $21 \mu \mathrm{m}$ thickness at 20, and (d) $40 \mu \mathrm{m}$ thickness at 40 hours. The thickness of formed nitride layer and formation and growth of crack on the surface increased proportionally to the screen plasma nitriding duration. Figure 3 (a) shows the formation of the layer without crack while Figure 3(b) shows the beginning of some cracks. Figure 3(c) shows the formation of new phase from the outer part while Figure 3(d) shows the large spread of the new phase $\left(\mathrm{Cr}_{\mathrm{x}} \mathrm{N}_{1-\mathrm{x}}\right.$ precipitated phase) throughout the nitrided layer.

It is well established that a higher nitriding potential induced by higher temperature causes brittleness to the S-phase, which is associated with high stress induced by composition, a high yield stress and limited ductility [8] [9].

$\mathrm{X}$-ray diffraction patterns of the ASS samples at different processing steps are shown in Figure 4. Diffraction patterns of FCC iron structure were observed indicating the status of the non-treated ASS.

The crystallographic data of the nitrided ASS provide information including phase identity as well as lattice strain induced by internal stress. The diffusion of nitrogen atoms into the octahedral interstitials of the ASS substrate leads to the 


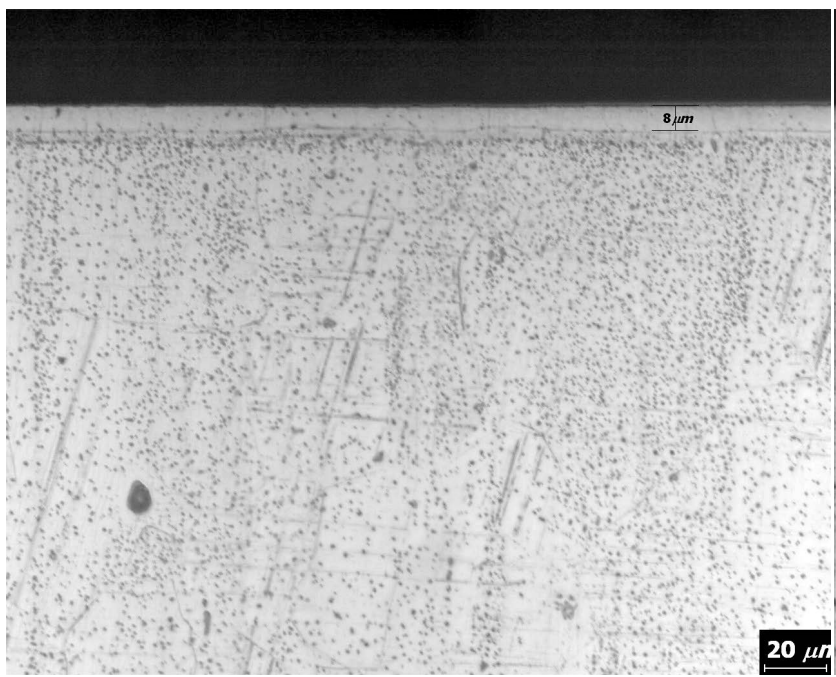

(a)

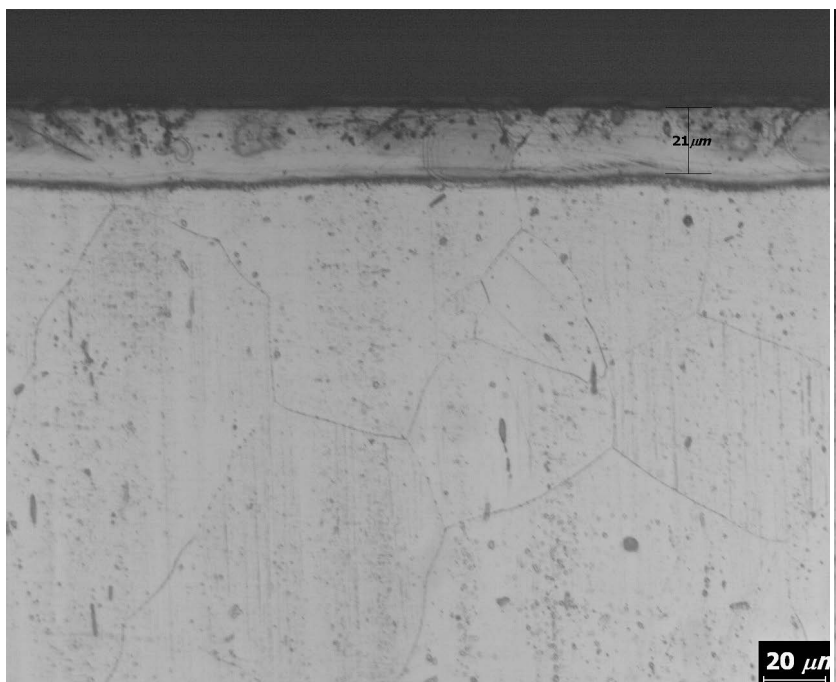

(c)

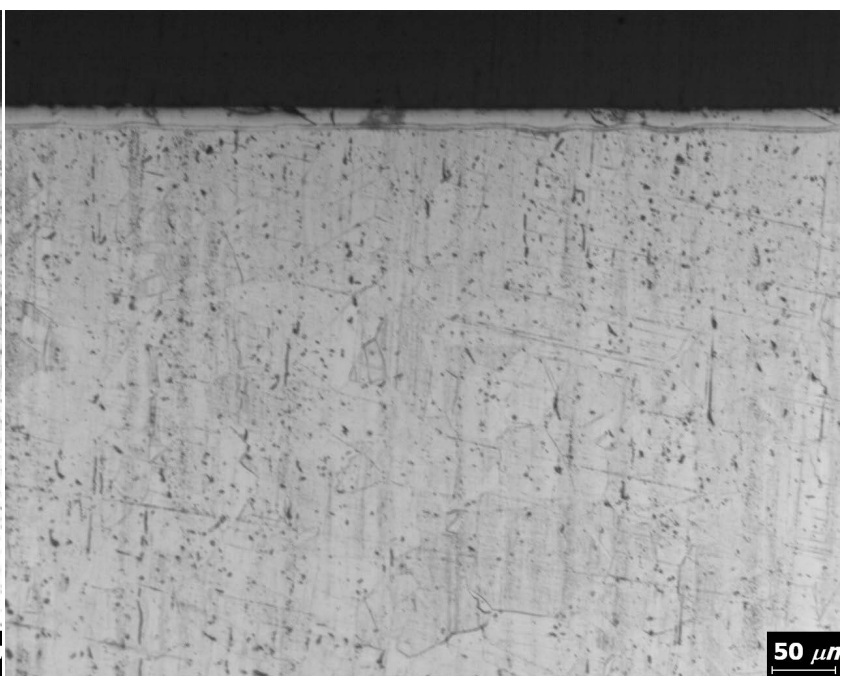

(b)

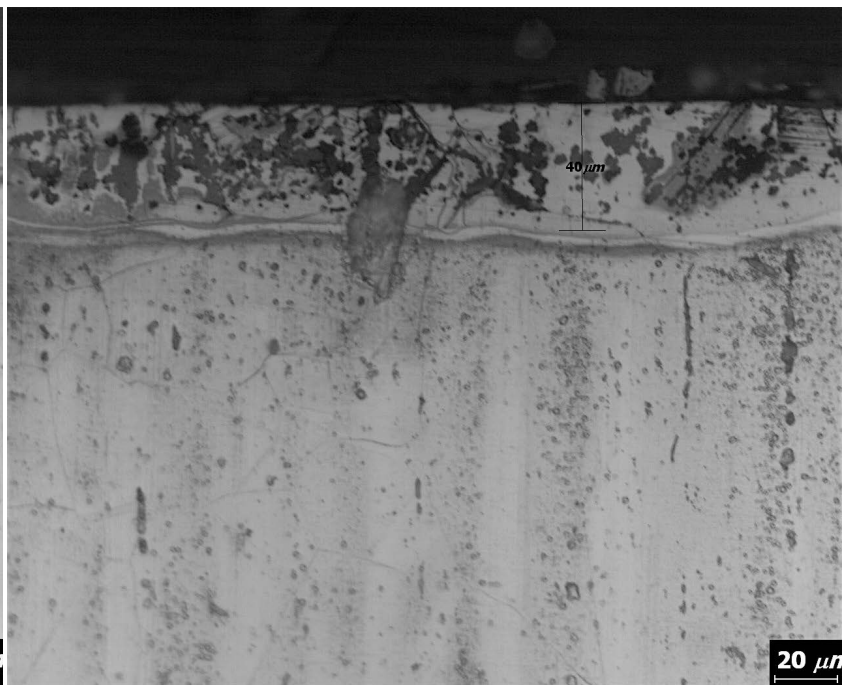

(d)

Figure 3. Cross section images of the SPN treated ASS with different time at (a) 4, (b) 10, (c) 20, and (d) 40 hours.

expansion of unit cells in the S-phase during the nitriding process different times. In addition to this, the fault (i.e. stacking fault) of the face centered cubic (FCC) lattice causes $2 \theta$ peak shift to the nitrided ASS, compared to the bare ASS [11] [12].

For the S-phase prepared at $713 \mathrm{~K}$, peak shift to the lower $2 \theta$ angle as well as peak broadening with different diffusion concentration, about $3^{\circ}$ and over, are clearly shown, which imply that the unit cell volume expands due to the larger amount of nitriding-induced nitrogen interstitials in the S-phase [8].

Comparison of ASS raw material and X-ray peak by the SPN process as shown in Figure 4 indicates the formation of S-phase in the maximum grid constant after the sample is treated for 4 hours or longer. However, it also shows the peak becoming wider as it moves to the right again at $713 \mathrm{~K}$ and $20 \mathrm{hr}$, leading to the precipitation of nitride with epsilon phase $\left(\varepsilon-\mathrm{Fe}_{2-3} \mathrm{~N}\right)$ as the nitrogen leaves the 


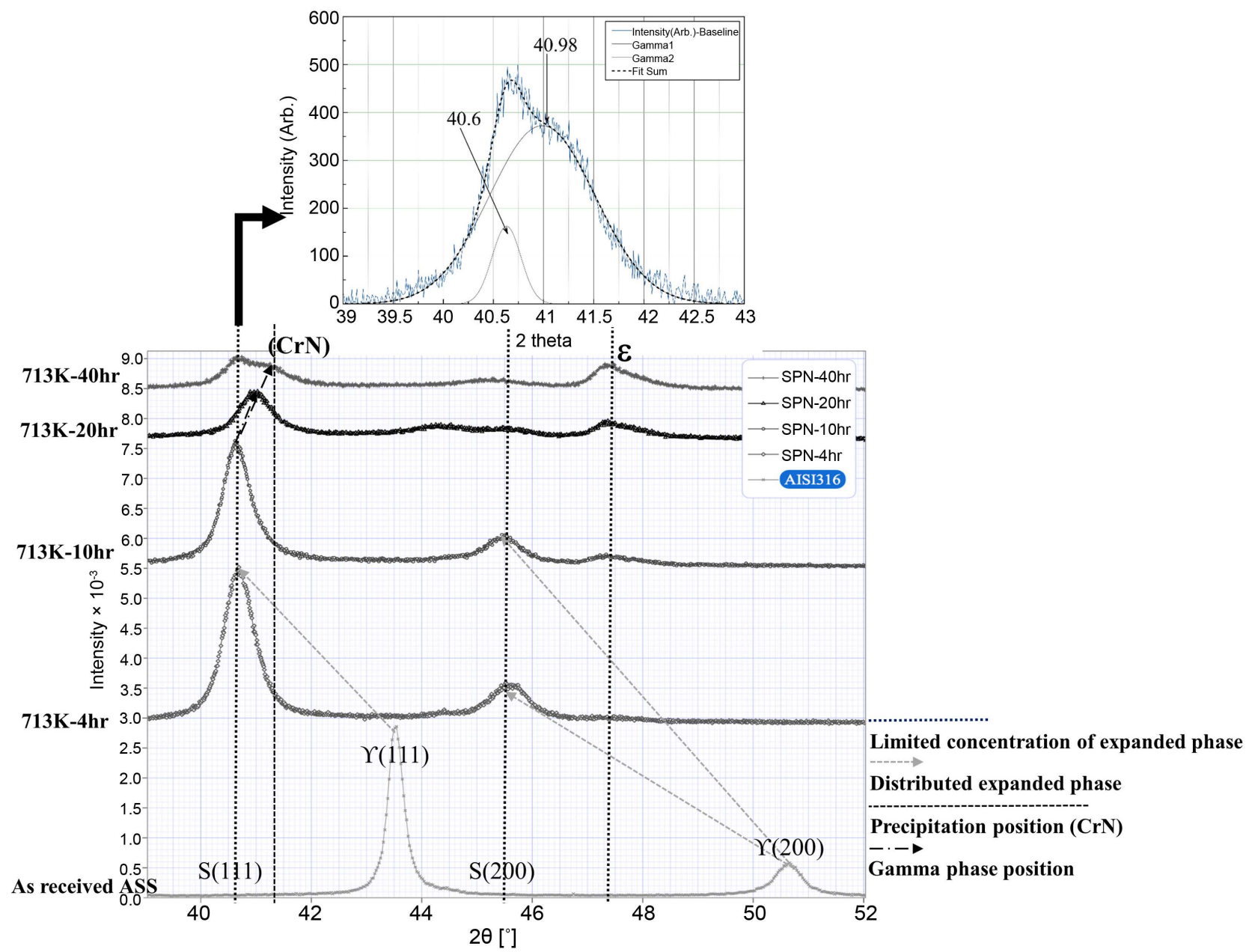

Figure 4. X-ray diffraction patterns of SPN treated layer at $713 \mathrm{~K}$ as functions of the treatment time.

grid. At $713 \mathrm{~K}$ and $40 \mathrm{hr}$, the peak is separated into two or more as shown in Figure 4. Such phenomenon confirms the fact that the change of tissue according to the nitriding time as shown in the images of cross section image with time in figure matches the change of X-ray peak according to the screen plasma nitriding time. And the longer the screen plasma nitriding time, the wider the $\mathrm{X}$-ray peaks, which indicate finer grain size. The fine grain size is expected to contribute to the increased strength and hardness of the alloy.

The distribution of hardness profile along the depth of the S-phase on ASS after SPN processing is depicted in Figure 5. Although the figure shows the typical hardness value of about $1300 \mathrm{HV}_{0.025}$ in the layer where the S-phase contains $\mathrm{CrN}$ precipitation, the maximum hardness was observed in positions where the nitrogen concentration was not particularly high. To explain such high hardness, P. A. Dearnley [5] and T. Christiansen [13] reported the maximum hardness of about $20 \mathrm{GPa}$ when the nitrogen content in the S-phase was of 8 and maximum of about 30 at $\%$ and then a lower value with the additional precipitation of phase.

On the other hand, X. Y. Li et al. analyzed the phase with X-TEM and reported 

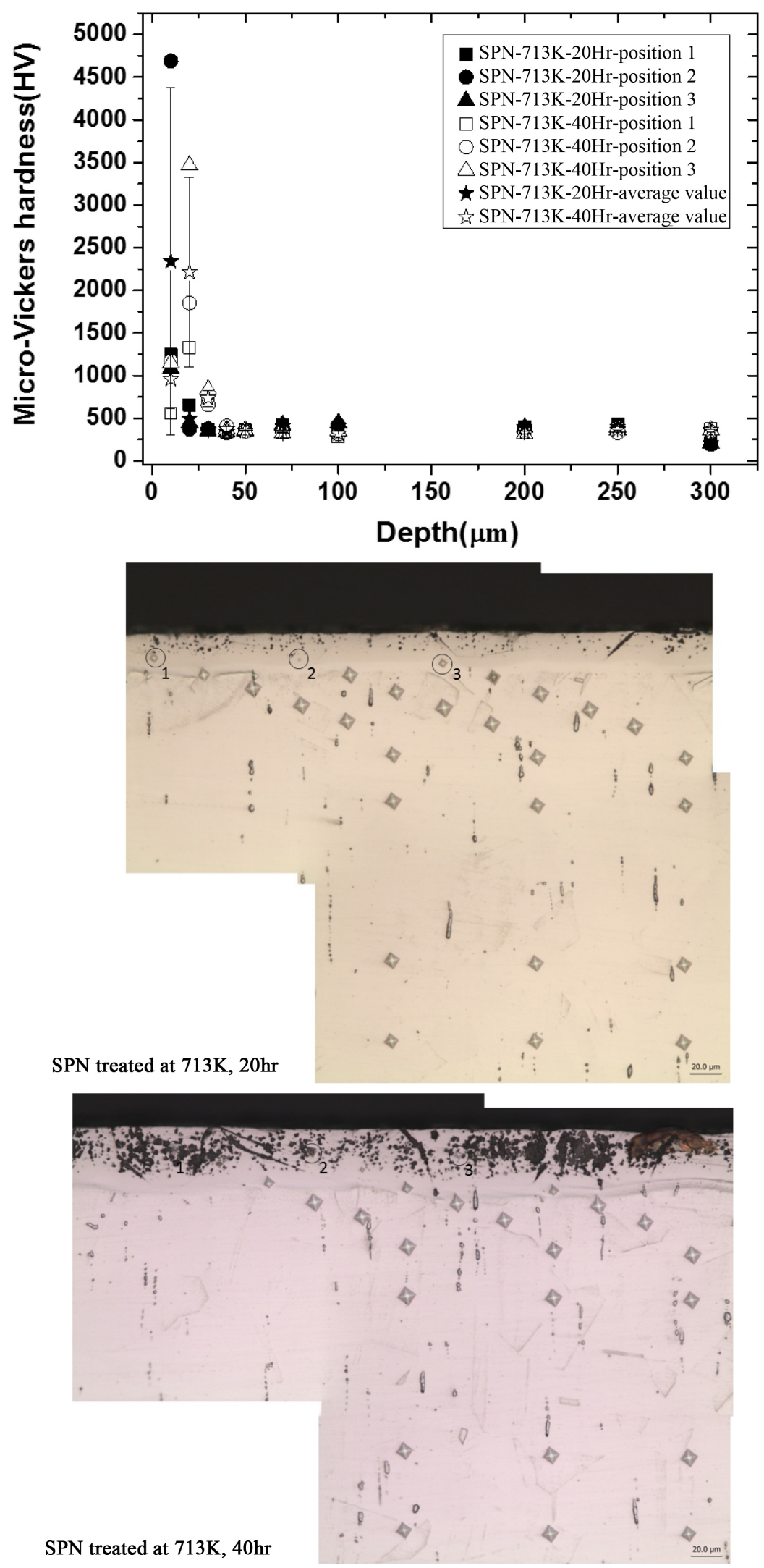

Figure 5. Hardness-depth profile of the nitriding layers via SPN on the ASS prepared at $713 \mathrm{~K}$ for $20 \mathrm{hr}$ and $40 \mathrm{hr}$. 
that the difficulty of dislocation in the S-phase increased the hardness and the hardness increased to an extreme level by increase of phases (mostly $\gamma-\mathrm{M}_{4} \mathrm{~N}, \mathrm{M}=$ $\mathrm{Cr}, \mathrm{Fe}$, and Mo etc.) precipitated in the sublayer, that is the phase [14].

The study of phase distribution showed the difference of precipitation phase according to depth. However, the phenomenon must be analyzed with the phase structure and thus is excluded from this study.

Figure 6 shows the results of the line scanning and mapping according location-specific EDS. Figure 6(a) shows the compositional at positions 1 through 4 at each depth of the layer, and Figure 6(b) shows the result of S-phase component analysis with line scanning and indicates the similar component distribution at each depth. Figure 6(c) shows the result of EDS mapping of the S-phase layer and indicates that the stains on the S-phase are in the form of $\mathrm{Cr}$ and $\mathrm{Mo}$ nitrides.

Diffusion profile of the nitrogen atoms in the ASS is closely related with the concentration-dependent diffusivity of nitrogen atoms along the depth of the S-phase. The nitrogen potentials are reflected in the atomic concentration-depth profile of the nitrided layer on ASS as shown in Figure 7.

In Figure 7, the atomic concentration of nitrogen near the surface of S-phase is 44 at\% which implies that the nitrogen contents at the surface increase during the SPN 20 hours treatment. Particularly, a steep increase of the nitrogen concentration towards the surface of the S-phase after the smooth increase of the nitrogen gradient from the ASS substrate was observed on the sample.

Interestingly, a very small amount of carbon atoms was observed at the location where diffusion of nitrogen atoms towards the ASS substrate halts, as shown in the insets of the Figure 5, which implies that carbon atoms in bare ASS are pushed ahead by the diffusion of nitrogen atoms during screen plasma nitriding procedure.

Comparison of the gradient of nitrogen concentration in Figure 7 and the images of $713 \mathrm{~K}$ for $20 \mathrm{hr}$ and observed hardness in Figure 5 indicates that the nitrogen concentration showing the maximum hardness is at 20 at\%, not 44 at\%.

\section{Conclusions}

The S-phase of the ASS was prepared using SPN treatment at different times. The prior studies have focused on decreasing deterioration of corrosion resistance due to a formation of S-phase. However, increasing the process time of S-phase will result in precipitation of new phase in the S-phase by the $\mathrm{CrN}$ and the contents in ASS.

The SPN treatment of sample at the temperature of $713 \mathrm{~K}$ for 4 hours showed no precipitation phase or crack initially and then the fine cracks beginning to form after 10 hours and the precipitation phase observed in the S-phase at 20 hours. The precipitation phase spread throughout the whole S-phase after 40 hours. The result showed that the phase-forming behavior agreed well with the peak shift and the phase separation phenomenon of the X-ray diffraction pattern. 


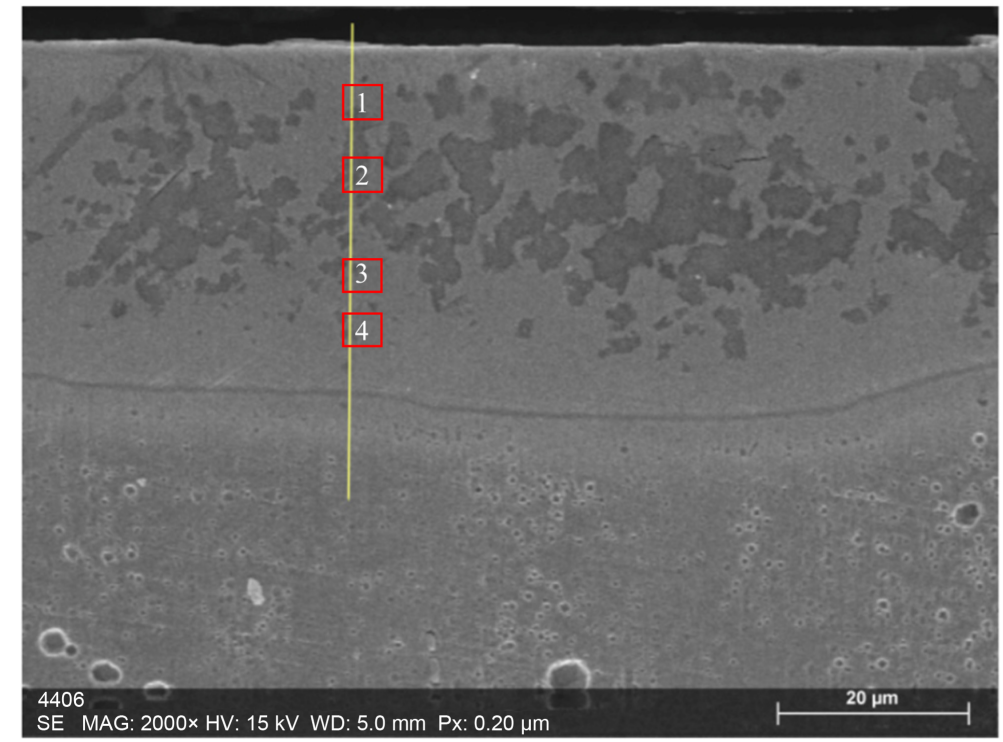

$\begin{array}{llllll}\text { Name } & \text { Date } & \text { Time } & \begin{array}{c}\text { HV } \\ {[\mathrm{kV}]}\end{array} & \text { Mag } & \begin{array}{c}\text { WD } \\ {[\mathrm{mm}]}\end{array} \\ 4406 & 5 / 23 / 2017 & 4: 39: 11 \mathrm{PM} & 15.0 \mathrm{keV} & 2000 \times & 5.0 \mathrm{~mm}\end{array}$

1 Element At. No. Line s. Mass Mass Norm. Atom abs. error [\%] $\begin{array}{llllll} & \text { (1 sigma) }\end{array}$ $\begin{array}{rrrrrr}\text { Carbon } & 6 \text { K-Serie } & 2.79 & 3.08 & 10.44 & 0.80\end{array}$ $\begin{array}{llllll}\text { Nitrogen } & 7 \text { K-Serie } & 4.82 & 5.33 & 15.49 & 1.10\end{array}$

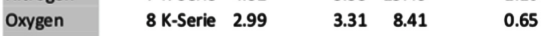
$\begin{array}{llllll}\text { Sulfur } & 16 \text { K-Serie } & 0.94 & 1.04 & 1.32 & 0.07\end{array}$ $\begin{array}{lllll}\text { Chromium 24 K-Serie 17.34 } & 19.17 \quad 15.00 & 0.57\end{array}$

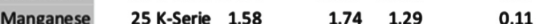
\begin{tabular}{l|lrrrr} 
Iron & 26 K-Serie 51.99 & 57.45 & 41.88 & 1.62
\end{tabular}

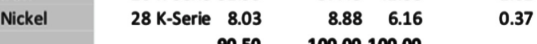

2 Mass Mass Norm. Atom abs. error [\%] $\begin{array}{llllll}\text { Element At. No. Line s. }[\%] & {[\%]} & {[\%]} & \text { (1 sigma) }\end{array}$ $\begin{array}{lrrrrr}\text { Carbon } & 6 \text { K-Serie } & 3.36 & 3.85 & 12.18 & 0.91\end{array}$ $\begin{array}{llllll}\text { Nitrogen } & 7 \text { K-Serie } & 5.65 & 6.49 & 17.59 & 1.24\end{array}$ $\begin{array}{lllllll}\text { Oxygen } & 8 \text { K-Serie } & 3.76 & 4.31 & 10.24 & 0.78\end{array}$ $\begin{array}{lrrrrrr}\text { Oxygen } & 8 \mathrm{~K} \text {-Serie } & 3.76 & & 4.31 & 10.24 & 0.78 \\ \text { Sulfur } & 16 \mathrm{~K} \text {-Serie } & 1.43 & & 1.64 & 1.95 & 0.09\end{array}$ $\begin{array}{llrrrr}\text { Sulfur } & 16 \text { K-Serie } & 1.43 & 1.64 & 1.95 & 0.09 \\ \text { Chromium } & \text { 24 K-Serie } 23.12 & 26.55 & 19.39 & 0.74\end{array}$

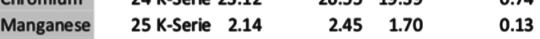
Iron $\quad \begin{array}{lllll}\text { 26 K-Serie 41.71 } & 47.89 & 32.56 & 1.33\end{array}$ Nickel $\quad 28$ K-Serie $5.93 \quad 6.81 \quad 4.41$

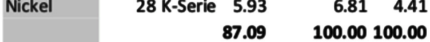

3 Element At. No. Line s. Mass Mass Norm. Atom abs. error [\%]

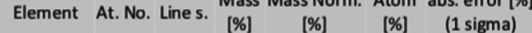
$\begin{array}{lrrrrr}\text { Carbon } & 6 \text { K-Serie } & 2.49 & 2.83 & 10.00 & 0.75\end{array}$ $\begin{array}{lllllll}\text { Nitrogen } & 7 \text { K-Serie } & 4.29 & 4.87 & 14.77 & 1.01\end{array}$ $\begin{array}{lllllll}\text { Oxygen } & 8 \text { K-Serie } & 1.55 & 1.76 & 4.67 & 0.41\end{array}$

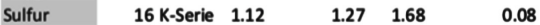
Chromium 24K-Serie $19.57 \quad 22.20 \quad 18.14 \quad 0.64$ $\begin{array}{llrrrrr}\text { Manganese } & 25 & \text { K-Serie } & 2.09 & 2.37 & 1.84 & 0.13\end{array}$ $\begin{array}{llrrrr}\text { Manganese } & 25 \text { K-Serie } & 2.09 & 2.37 & 1.84 & 0.13 \\ \text { Iron } & 26 \text { K-Serie } 49.86 & 56.57 & 43.02 & 1.56\end{array}$

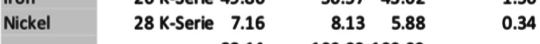

4 Element At. No. Line Mass Mass Norm. Atom abs. error [\%] Element At. No. Lines. [\%] [\%] [\%] (1 sigma) $\begin{array}{llllll}\text { Carbon } & 6 \text { K-Serie } & 2.40 & 2.56 & 9.63 & 0.75\end{array}$ $\begin{array}{llllll}\text { Nitrogen } & 7 \text { K-Serie } & 3.29 & 3.50 & 11.30 & 0.85\end{array}$

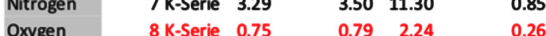
$\begin{array}{lrllll}\text { Oxygen } & 8 \text { K-Serie } & 0.75 & 0.79 & 2.24 & 0.26 \\ \text { Sulfur } & 16 \text { K-Serie } & 0.87 & 0.93 & 1.31 & 0.07\end{array}$ \begin{tabular}{llrrrr} 
Sulfur & 16 K-Serie & 0.87 & 0.93 & 1.31 & 0.07 \\
\hline Chromium & 24 K-Serie 16.98 & 18.06 & 15.72 & 0.56
\end{tabular} $\begin{array}{llllll}\text { Manganese } & 25 \mathrm{~K} \text {-Serie } & 180 & 1.92 & 1.58 & 0.12\end{array}$ $\begin{array}{lllll}\text { Iron } & 26 \text { K-Serie 59.47 } & 63.24 & 51.26 & 1.85\end{array}$ $\begin{array}{llrrrr}\text { Iron } & 26 & \text { K-Serie } 59.47 & 63.24 & 51.26 & 1.85 \\ \text { Nickel } & 28 \text { K-Serie } & 8.48 & 9.02 & 6.95 & 0.39\end{array}$

(a)
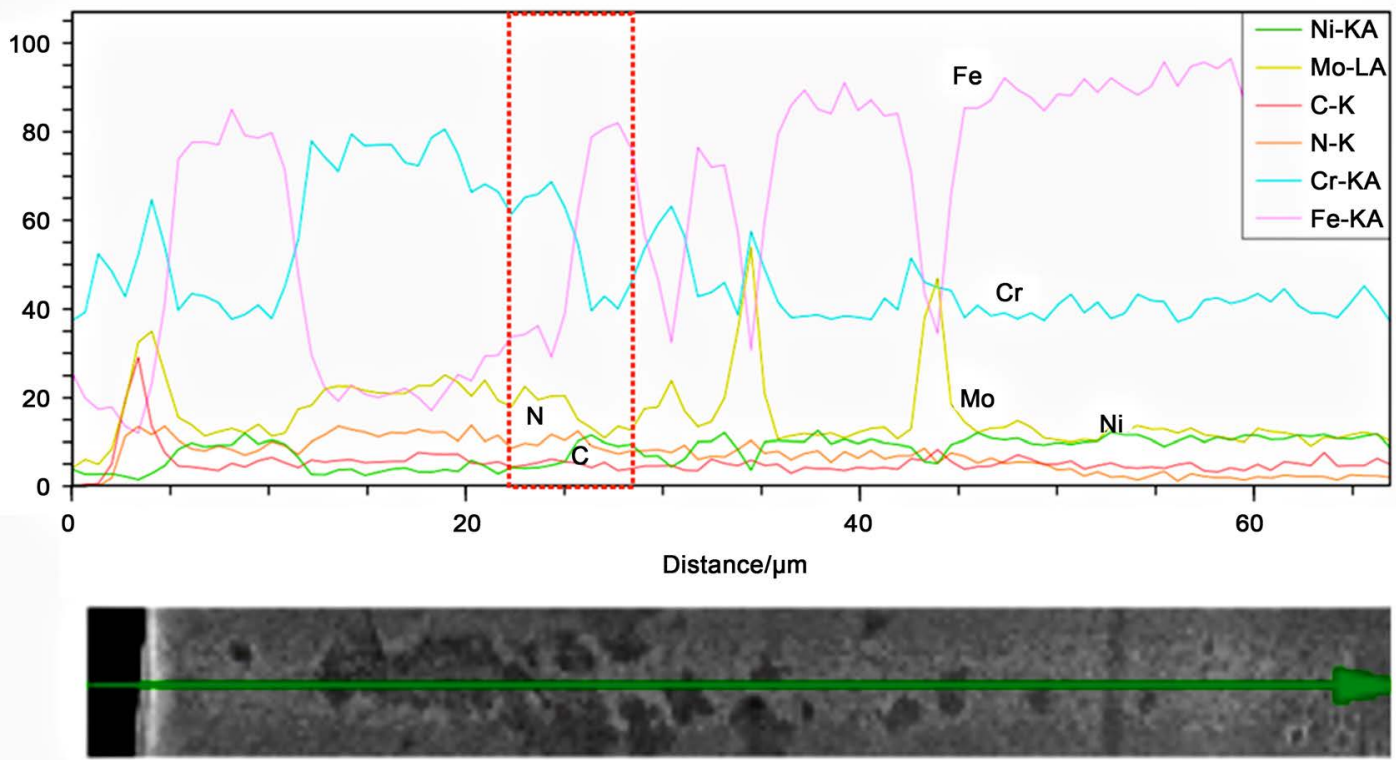

$\begin{array}{lllll}\text { Name } & \text { Date } & \text { Time } & \text { Points } & \begin{array}{l}\text { Length } \\ {[\mathrm{mm}]}\end{array} \\ \text { Scan data } & 5 / 23 / 2017 & 4: 48: 37 \text { PM } & 100 & 66.9 \mu \mathrm{m}\end{array}$
$5 / 23 / 2017$

(b) 

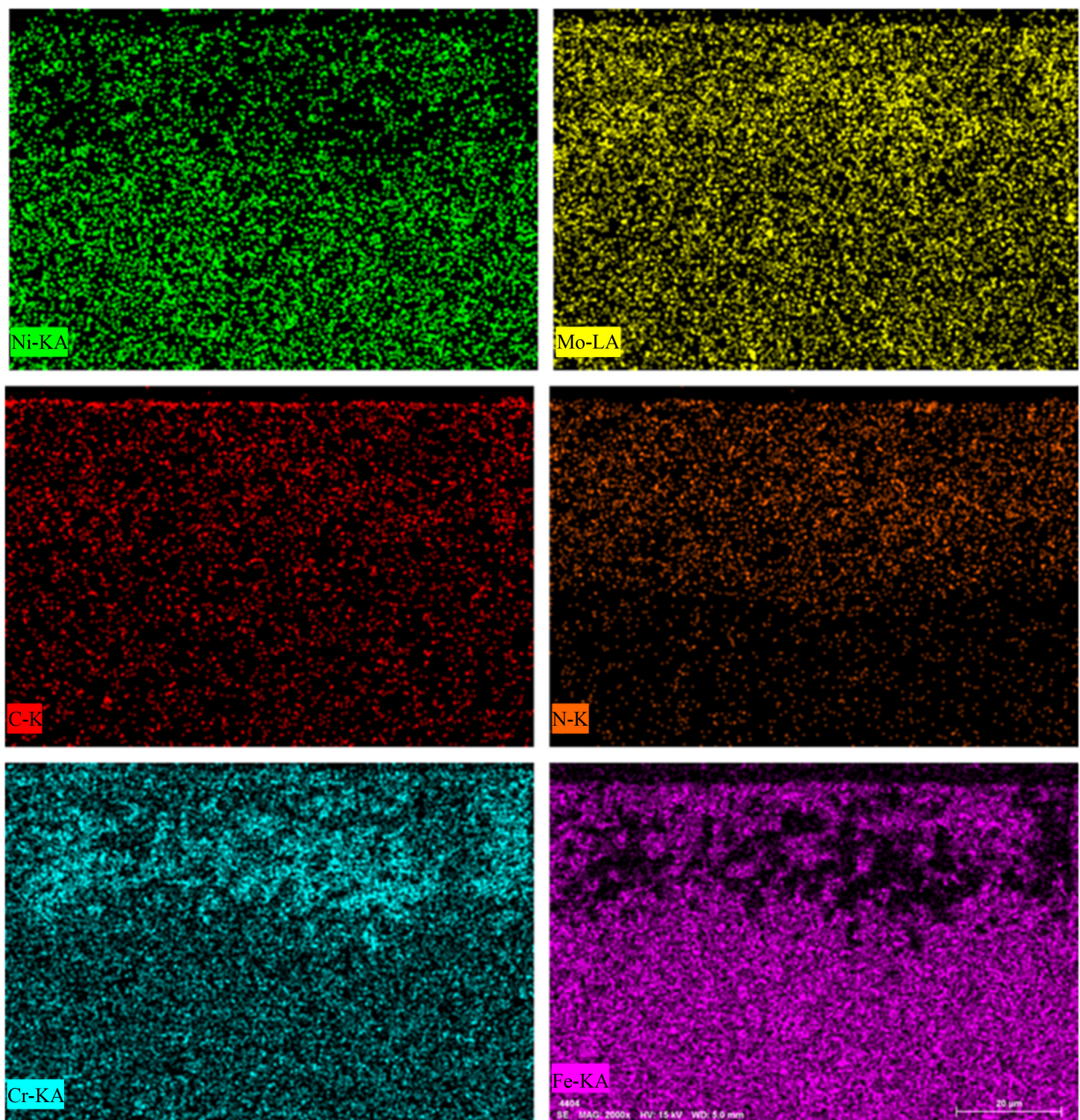

(c)

Figure 6. Result of line profiling of each position of S-phase layer and mapping of nitride layer using SEM/EDS. (a) Component analysis of 1 - 4 position of S-phase by point scanning. (b) Component analysis of S-phase by line scanning. (c) Component analysis by mapping of S-phase.

On the other hand, the analysis of hardness according to the time of S-phase formation showed a very high hardness value of $4689 \mathrm{HV}_{0.025}$ after 20 hours. The value was notable in that it was much higher than the hardness value according to formation of S-phase and that such high hardness value was observed at the position of about 20 at\% instead of the maximum nitrogen concentration of 44 at\%. We did not find any other precipitation on the position and are currently carrying out an in-depth study.

Under a circumstance, we consider the phenomenon very important because it means the possible development of the layer that shows the maximum hardness of $4689 \mathrm{HV}$ as the result of new precipitation phase in the form of GP-zone 


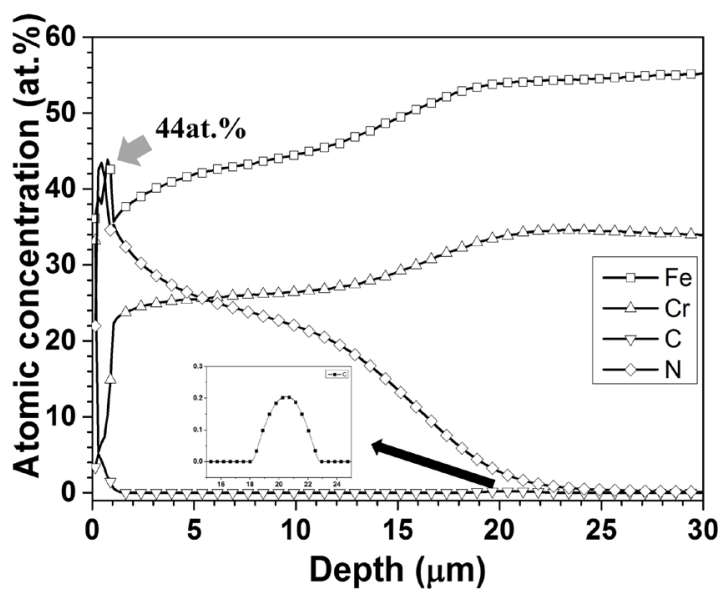

Figure 7. Atomic concentration of different atoms (Fe, $\mathrm{N}, \mathrm{C}$, and $\mathrm{Cr}$ ) along the depth of the S-phase layer on the ASS prepared via SPN process at $713 \mathrm{~K} 20 \mathrm{hr}$.

by aging and lattice parameter change of nitrogen during cooling.

It suggests the direction for the development of new methods of SPN treatment if a high degree of wear resistance is necessary even if it means some deterioration of corrosion resistance.

\section{References}

[1] Zhao, C., Li, C.X., Dong, H. and Bell, T. (2006) Study on the Active Screen Plasma nitriding and Its Nitriding Mechanism. Surface and Coatings Technology, 201, 2320. https://doi.org/10.1016/j.surfcoat.2006.03.045

[2] Han, L., Daia, J.T., Huang, X.R. and Zhao, C. (2013) Study on the Fast Nitriding Process of Active Screen Plasma Nitriding. Physics Procedia, 50, 94. https://doi.org/10.1016/j.phpro.2013.11.017

[3] Li, C.X., Georges, J. and Li, X.Y. (2002) Active Screen Plasma Nitriding of Austenitic Stainless Steel. Surface Engineering, 18, 453. https://doi.org/10.1179/026708402225006240

[4] Samandi, M., Shedden, B.A., Smith, D.F.I., Collins, G.A., Hutchings, R. and Tendys, J. (1993) Microstructure, Corrosion and Tribological Behaviour of Plasma Immersion Ion-Implanted Austenitic Stainless Steel. Surface and Coatings Technology, 59, 261. https://doi.org/10.1016/0257-8972(93)90094-5

[5] Dearnley, P.A. (2002) Corrosion Wear Response of S Phase Coated 316L. Surface Engineering, 18, 429. https://doi.org/10.1179/026708402225006277

[6] Zhang, Z.L. and Bell, T. (1985) Structure and Corrosion Resistance of Plasma Nitrided Stainless Steel. Surface Engineering, 1, 131. https://doi.org/10.1179/sur.1985.1.2.131

[7] Schramm, R.E. and Reed, R.P. (1975) Stacking Fault Energies of Seven Commercial Austenitic Stainless Steels. Metallurgical and Materials Transactions A, 6A, 1345. https://doi.org/10.1007/BF02641927

[8] Christiansen, T.L. and Somers, M.A.J. (2009) Low-Temperature Gaseous Surface Hardening of Stainless Steel: The Current Status. International Journal of Materials Research, 100, 1361. https://doi.org/10.3139/146.110202

[9] Kim, S.-G., Lee, J.-H., Saito, N. and Takai, O. (2013) The Role of Activated Nitrogen 
Species on Double-Folded Screen Nitriding Process. Journal of Physics: Conference Series, 417, 1. https://doi.org/10.1088/1742-6596/417/1/012023

[10] Yeo, K.-H., Kim, S.-G., Lee, J.-H., Kong, J.-H. and Okumiya, M. (2014) Trend of Nitriding on Chromium-Molybdenum Steel via Low Temperature Screen Plasma Technology. Advances in Materials Physics and Chemistry, 4, 141. https://doi.org/10.4236/ampc.2014.48017

[11] Velterop, L., Delhez, R., de Keijser, Th.H., Mittemeijer, E.J. and Reefman, D. (2000) X-Ray Diffraction Analysis of Stacking and Twin Faults in f.c.c. Metals: A Revision and Allowance for Texture and Non-Uniform Fault Probabilities. Journal of Applied Crystallography, 33, 296. https://doi.org/10.1107/S0021889800000133

[12] Fewell, M.P. and Priest, J.M. (2008) High-Order Diffractometry of Expanded Austenite Using Synchrotron Radiation. Surface and Coatings Technology, 202, 1802. https://doi.org/10.1107/S0021889800000133

[13] Christiansen, T., Dahl, K.V. and Somers, M.A.J. (2008) Nitrogen Diffusion and Nitrogen Depth Profiles in Expanded Austenite: Experimental Assessment, Numerical Simulation and Role of Stress. Materials Science and Technology, 24, 159. https://doi.org/10.1179/026708307X232901

[14] Li, X.Y., Sun, Y., Bloyce, A. and Bell, T. (1997) XTEM Characterisation of Low Temperature Plasma Nitrided AISI 316 Austenitic Stainless Steel. Institute of Physics Conference Series No. 153: Section 13, 633. 